8-2007

\title{
Vigilantism, Current Racial Threat, and Death Sentences
}

David Jacobs

Ohio State University

Stephanie L. Kent

University of Nevada, Las Vegas

Jason T. Carmichael

Ohio State University - Main Campus

Follow this and additional works at: https://engagedscholarship.csuohio.edu/clsoc_crim_facpub

Part of the Criminology Commons

How does access to this work benefit you? Let us know!

Publisher's Statement

This research was partially supported by National Science Foundation (NSF) grant \#0417736.

\section{Repository Citation}

Jacobs, David; Kent, Stephanie L.; and Carmichael, Jason T., "Vigilantism, Current Racial Threat, and Death Sentences" (2007). Sociology \& Criminology Faculty Publications. 108.

https://engagedscholarship.csuohio.edu/clsoc_crim_facpub/108

This Article is brought to you for free and open access by the Sociology \& Criminology Department at EngagedScholarship@CSU. It has been accepted for inclusion in Sociology \& Criminology Faculty Publications by an authorized administrator of EngagedScholarship@CSU. For more information, please contact library.es@csuohio.edu. 


\section{Vigilantism, Current Racial Threat, and Death Sentences}

David Jacobs

Ohio State University

Stephanie L. Kent

University of Nevada, Las Vegas
Jason T. Carmichael

Ohio State University

Capital punishment is the most severe punishment, yet little is known about the social conditions that lead to death sentences. Racial threat explanations imply that this sanction will be imposed more often in jurisdictions with larger minority populations, but some scholars suggest that a tradition of vigilante violence leads to increased death sentences. This study tests the combined explanatory power of both accounts by assessing statistical interactions between past lynchings and the recent percentage of African Americans after political conditions and other plausible effects are held constant. Findings from count models based on different samples, data, and estimators suggest that racial threat and lynchings combine to produce increased death sentences, but the presence of liberal political values explains the absence of death sentences. These findings both confirm and refine the political version of conflict theory because they suggest that the effects of current racial threat and past vigilantism largely directed against newly freed slaves jointly contribute to current lethal but legal reactions to racial threat.

$\mathrm{I}_{\mathrm{r}}$ s there a connection between lynchings and recent attempts to impose the death penalty? Many studies have analyzed individual trial court decisions to discover whether racial discrimination influences the likelihood of a death sentence. After holding legal effects constant, such as the severity of the crime and the offender's prior convictions, these studies have used offender race to explain death sentences. Despite strong suspicions that the death penalty is not

Direct all correspondence to David Jacobs, Department of Sociology, 300 Bricker, 190 North Oval Mall, Ohio State University, Columbus, $\mathrm{OH}$ 43210. The authors thank Bob Kaufman, Jim Moody, Bob O'Brien, and Ruth Peterson for their helpful advice, and Stuart Tolnay and Andrew Hanssen for the data they supplied. All data used in this study and in unreported analyses mentioned in this article are available on request. This research was partially supported by National Science Foundation (NSF) grant \#0417736. administered in a color-blind fashion, findings about offender race have been inconsistent (see Dodge et al. 1990 and Paternoster 1991 for reviews). These studies, however, may be inconclusive because they ignore the remarkable history of race relations in the United States.

In comparison to other nations, U.S. race relations have been exceptionally antagonistic and violent (Myrdal 1944; Tocqueville [1935] 1948). After African American slaves were freed by a brutal Civil War, white citizens sought to maintain the prior racial caste system with illegal violence directed largely against ex-slaves. From 1882 to 1951 , more than 4,600 persons were lynched (Tolnay and Beck 1996). Although most of these acts took place in the South from 1882 to 1930 , many occurred in other regions during this period. In the Jim Crow South, a set of social and legal codes enforced by legal coercion and vigilantism ensured the separation of the races and almost complete black subjugation (Wacquant 2000). Many scholars have claimed that the current death penalty is a partial replace- 
ment for vigilantism used in the past to maintain this caste system (Bowers 1984; Dollard 1957; Marable 2000; Phillips 1987). This claim seems plausible because the states that once had the highest lynching rates now appear to use the death sentence most often (Zimring 2003). Yet despite the extraordinary nature of this violence, the effects of lynchings have been infrequently investigated.

In this study we attempt to fill this gap by focusing on whether the vigilantism used primarily to control ex-slaves created an enduring repressive tradition that continues to produce additional death sentences where lynchings had been most common. Theoretical accounts suggest that such explanations should matter. Stone (1987) claimed that the death penalty was used by powerful groups to protect their privileges with selective terror. Garland (1990) argued that criminal punishment is shaped not only by the amount or severity of crime, but also by perceptions about the menace of "problem populations." According to conflict theorists, an important, but not the only, use of the law is to control underclass populations who pose a threat to the current unequal social order. If criminal punishments are shaped partly by the menace of a racial underclass whose members have much to gain from violence used to take goods from the privileged, a harsh punishment such as the death sentence should be more likely where such threats are most severe.

We analyze recent death sentences to discover whether the vigilantism directed largely against blacks in the past and current racial threats to white dominance attributable to larger black populations operate together to produce additional death sentences. Evidence for such a combined relationship between prior vigilantism and recent minority threat would support claims that the death sentence is currently imposed partly because it is a legal and therefore more acceptable replacement for lynchings. These considerations suggest that death sentences should be especially likely in states with the largest minority populations that also had a history of frequent vigilante violence.

In light of the intense interest in the death penalty and the controversies about whether this punishment is administered impartially, it is surprising that we know so little about the influence of race and the other social conditions that make some jurisdictions far more likely to impose this sentence than others. We begin to fill this gap in the literature by using pooled time-series, cross-sectional count models that capture both jurisdictional differences in this outcome and shifts in the number of death sentences over time. ${ }^{1}$ We study death sentences rather than executions for important methodological reasons (see note 6), but also because the initial decisions to begin the death penalty process by prosecutors and trial courts are so important. Because single-factor explanations are suspect, we assess many hypotheses, but this means the next section cannot deal with the theoretical justifications for only a few explanations.

\section{THEORY}

We expect that the historical residue of the rancorous and violent conflicts about slavery still influences the ultimate criminal punishment. To address this issue, we assess the combined ability of lynchings and current black threat to explain recent death sentences. In additional analyses, we discover whether this joint effect explains African American death sentences and whether this effect accounts for these sentences in 10 southern states. We begin by discussing lynchings and the reasons why this historical violence should continue to influence recent death sentences. We next spell out the theoretical grounds for expecting a connection between racial threat and criminal punishment. The last part of this section presents the reasons for thinking that other effects should be held constant in the analyses.

${ }^{1}$ In 1972 in Furman the Supreme Court ruled that the death penalty was unconstitutional. In 1976, in Gregg the Court reversed and upheld the constitutionality of guided discretionary statutes combined with a separate sentencing procedure. To achieve cross trial court sentencing equity the Court required standardized instructions to juries listing aggravating or mitigating factors to be considered in the separate penalty hearing (Paternoster 1991). Most death penalty states then altered their statutes to meet these new requirements. We include period controls to capture shifts in death sentences attributable to these decisions and other unmeasured historical events that might influence the results. 


\section{MINORITY THREAT, VIGILANTISM, AND DEATH SENTENCES}

Lethal Vigilantism. A common dominant group reaction to the threat to their ascendance posed by larger minority populations involves extralegal violence. The lynching of ex-slaves that occurred after Reconstruction is an excellent example (Tolnay and Beck 1996). Black (1976) has argued that because they are used for the same ends, illegal and legal social control methods are at least partly interchangeable. Phillips (1987:365), quoting Turk (1982:351), claimed that "both official and unofficial killings constitute 'behavior intended to establish and maintain an unequally beneficial relationship." According to many scholars, whites often used lynchings to control ex-slaves and to ensure that they did not forget their subordinate place in a racial caste system (Ayers 1984; Dollard 1957; Tolnay and Beck 1996). Yet although many historians (particularly Ayers 1984; Brown 1969; and Woodward 1966) and some sociologists (Corzine, Corzine, and Creech 1988; Corzine, Creech, and Corzine 1983; Olzak 1990; Reed 1972; Soule 1992; Tolnay and Beck 1996) have assessed the determinants of lynchings, few have studied the legal consequences of this mass violence.

Whites in the Jim Crow South clearly viewed lynching as a replacement for capital punishment (Dollard 1957; Phillips 1987; Tolnay and Beck 1996). Dollard captured this complementary relationship between legal and extralegal violence by writing: "the crux of the matter is white control of formal force, the police, sheriffs, justices of the peace, judges, and juries ... [but] extralegal force supplements and supports these legal actions" (p. 333). Equivalent claims were made by lynch mobs. In a contemporary apology for lynchings, Collins (1918:57) quoted a resolution by a lynch mob that "in the event of a trial (the offender) shall be hanged." These vigilantes went on to justify their act with the claim that a trial would be a sham because "there is no moral difference in the means of destroying him." Phillips gave another example when he discussed a temporary increase in lynchings that occurred in Colorado after capital punishment briefly became illegal. Contemporary newspaper accounts attributed this increase in illegal violence to the elimination of capital punishment as a legal alternative to lynchings. If these claims about the interchangeability of legal and extralegal reactions to racial threat in the past are correct, a tradition of lethal vigilantism may still help produce recent death sentences because the death penalty now may be used partly as a legal replacement for this vigilante violence.

We therefore suggest that the vigilantism largely intended to ensure that newly freed blacks reverted to their prior subordinate status had enduring effects on another lethal punishment. Assertions about the historical force of such lengthy causal chains based on the power of tradition are hardly novel. Durkheim "lamented that many social facts 'continue to exist merely through force of habit' among them antiquated penal ... institutions ... 'that time has fixed and organized in us" (Camic 1986:1051-52 quoting Durkheim [1895]. 1982; see also Ogburn 1937 for additional discussions of cultural lag). ${ }^{2}$

The aberrant nature of this repeated violence, which went so far beyond even the accepted standards of the day (Tolnay and Beck 1996), shows the intensity of this mass commitment to racial domination. Wacquant (2000) used the enduring effects of concepts such as social impurity and taboo put forward by Douglas (1966) to help explain this persistence. Jim Crow and the lynchings that supported this regime maintained the "symbolic distance needed to prevent the odium of 'amalgamation' with a group considered inferior, rootless, and vile" (p. 380).

After the Civil Rights era "while whites begrudgingly accepted integration in principle, in practice they strove to maintain an unbridgeable social and symbolic gulf with their compatriots of African American descent. They abandoned public schools, shunned public

\footnotetext{
${ }^{2}$ Future power holders tend to have the same values as past power holders, so power in subsequent generations will work in the same direction as current institutions. "If power this year is used to commit the population to a value, the population itself in socializing its successors will preserve the value. And if activities of a society embody the value, any functions of these activities for other values and interests or any inertia in activities as such will tend to preserve patterns related to the value in the next generation. All three processes create infinite selfreplicating loops" (Stinchcombe 1987:108).
} 
space, fled to the suburbs in millions to avoid mixing, ... [and] they extended enthusiastic support for law and order policies" that helped to enforce these racial boundaries (p. 382). One implication is that where these enduring racial taboos had been most intensely enforced by illicit violence, the use of legal violence now can be expected to achieve the same ends.

The fervor that evoked this fierce repression suggests that violence used to ensure black subordination would endure in one form or another. But the unacceptability of vigilantism, particularly after the violent efforts to repress the Civil Rights movement that awakened the national conscience and destroyed Jim Crow, meant that this repression would have to take a different, more acceptable form. This fierce passion for violent control in the past nevertheless enhances the plausibility of claims that the harsh methods used to maintain the dominance of whites over blacks persist in sufficient strength to influence recent legal decisions about death sentences. "What distinguishes the saga of lynchings in the United States from other examples of mob violence in Western history are the volume of killings, the length of the period lynching was practiced ..., and its linkage to racial repression.... It is the lynching tradition as a historical institution that seems to have a lasting influence on capital punishment" (Zimring 2003:90). It follows that acts based on such passions and notions of racial impurity are likely to persist over long periods in contrast to behavior not based on such primordial sentiments.

Zimring (2003) went on to show how this local violence helped erode inhibitions about a legal death penalty. "The critical significance of a vigilante tradition .... is that it neutralizes a powerful argument against allowing the state to kill its enemies: the fear of government power" (p. 98). Such a tradition that regards the punishment of criminals as a local concern removes a major claim against a state-managed death penalty. "The citizen who has positive feelings about vigilante violence will identify more closely with the punishment process, [and] will think of punishment as a community activity" rather than as an act by a distrusted government separate from the community (p. 99). Vigilante customs thus reduced the public's normal distrust of the institution that administers the death penalty. Yet the main point is that the fierce mass passions based on taboos about racial impurity that had provided a foundation for this now unacceptable vigilantism could be expressed with a legal, and therefore far more acceptable, death penalty.

Despite its plausibility, apparently only Phillips (1987), Tolnay and Beck (1996), and Zimring (2003) have examined the relationship between lynching and capital punishment. ${ }^{3}$ Phillips' (1987) study of the links between lynchings and executions in North Carolina from 1889 to 1918 does not reveal consistent patterns, perhaps because he limited his analysis to correlations. Tolnay and Beck (1996) tentatively concluded that no association existed between these two forms of control in 10 southern states in the late 19th century, but they did not report tests for statistical interaction. Zimring (2003) claimed that a relationship exists between past lynchings and recent executions in all states, but he analyzed this association with bivariate cross-tabulations. In the light of Zimring's intriguing but less than authoritative results, and because current legal and past illicit killings may be used for the same repressive ends (Phillips 1987; Turk 1982), we expect the number of death sentences to be greater in states with a history of multiple lynchings because this tradition should still produce greater pressures on court officials and juries to impose the death penalty.

RACIAL THREAT. The threat of larger minority populations also should matter (Blumer 1958; Bobo and Hutchings 1996). Prejudice is greater where black presence is more substantial (Quillian 1995, 1996; Taylor 1998). With crime

${ }^{3}$ Zimring's (2003) theoretical stance on the conceptual links between lynchings and the current use of the death penalty differs somewhat from ours. We suspect that this relationship between lynchings and recent death sentences depends on the presence of African American populations that are substantial enough to pose a threat to dominant whites. We emphasize an interactive relationship between a tradition of racially repressive vigilantism, the current menace of large black populations, and capital punishment. Yet Zimring assumed that the relationship between lynchings and the death penalty is additive because this relationship does not depend on additional explanatory factors. 
rates controlled, Liska, Lawrence, and Sanchirico (1982) and Quillian and Pager (2002) found that black presence leads to enhanced fear of crime. Larger black populations produce increased votes for anti-minority candidates (Giles and Buckner 1993; Giles and Hertz 1994), who often support harsh punishments. A legal death penalty is likely in states with the most black residents (Jacobs and Carmichael 2002). Findings that public support for capital punishment is associated with black presence and racial prejudice (Barkan and Cohn 1994; Soss, Langbein, and Metelko 2003) also suggest that the number of death sentences will be greater in states with more blacks. In some states, Hispanics are the largest minority, so death sentences should be more frequent where Hispanic populations are largest.

This relationship may not be linear (Blalock 1967). Theory suggests that whites will make greater demands for punitive measures after expansions in black presence. Yet when such minority populations reach a threshold and their political influence becomes sufficient, the positive relationship between minority presence and punitive responses should become negative (Jackson and Carroll 1981). Further growth in black presence past this threshold should give this minority enough political influence to reduce death sentences. Hence, the relationship between the percentage of blacks and death sentences should be positive, but where the black population has reached a threshold, this relationship should become negative. Blacks need not reach majority status for this reversal to occur. Minorities instead need only expand to the point at which their votes can decide elections in jurisdictions where other voting blocs are evenly matched.

AN INTERACTIVE HYPOTHESIS. The links between these events, however, may be more complex. Historical outcomes can be contingent on the joint appearance of more than one set of conditions that must be present in sufficient strength. In the absence of a black population sufficiently large to pose a current threat, a prior tradition of vigilantism may not be enough to lead to additional death sentences. And without a history of frequent lynchings and a concomitant tradition that justified this exceptional mass violence, the threat posed by the current presence of a substantial African American pop- ulation may not be sufficient to produce increased death sentences. Repeated findings (Tolnay and Beck 1996) that lynchings were a reaction to the threat based on larger black populations enhance the plausibility of one link in this interactive account because such results suggest that larger black populations still may lead to lethal control methods.

Inclinations to use deadly force to sustain unequal relationships (Turk 1982) either can take the form of extralegal vigilantism or these proclivities can be expressed with legal sanctions that now may be partly used for the same repressive ends (Black 1976; Dollard 1957; Marable 2000; Phillips 1987). Claims about the interchangeability of lynchings and current death sentences rest on the presence of a welldocumented (Dollard 1957; Zimring 2003) repressive tradition that continues to make lethal reactions to racial threat acceptable to many citizens via the means described by Stinchcombe (1987), Wacquant (2000), and Zimring (2003). But the blatantly inequitable laws and vigilantism used in the Jim Crow era have become indefensible. A more acceptable alternative is to carry out lethal repression under the cloak of law. Because it is imposed by an ostensibly objective legal process, the death penalty provides an acceptable way to continue the use of lethal sanctions to control "problem populations." This replacement hypothesis leads to an expectation that an interactive relationship should be present because death sentences should be most common in states that currently have larger proportions of African Americans combined with a history of repeated lynchings.

Although it is not as probable, perhaps both black and white offenders were more likely to face the death sentence where lynchings had been most common because many whites were lynched even in the South (Tolnay and Beck 1996:270). Discrimination in the process that leads to death sentences is likely, but it is not overt. Literature reviews (Dodge et al. 1990; Paternoster 1991) conclude that the effects of offender race are not clear-cut. A black who kills a white is far more likely to be sentenced to death, but this racial pattern occurs in only about 3 percent of all murders. These considerations are consistent with a finding that the percentage of blacks on death row is proportional to the percentage of murders they com- 
mit (Blume, Eisenberg, and Wells 2004). It is plausible that overt and therefore indisputable discrimination in the death sentencing process would place the constitutionality of this punishment at risk. Perhaps a vigilante tradition may produce additional death sentences for all races (Zimring 2003) although the threat of this sanction is designed primarily to control underclass blacks. We expect that the racial accounts we test should nevertheless have greater explanatory power when black death sentences are at issue. But prudence and the informative contrasts that may appear suggest that we discover whether this interactive account explains all death sentences as well as those death sentences given only to blacks.

These interactive and nonlinear threat relationships between African American presence, lynching rates, and death sentences lead to an additional prediction based on conflict and racial threat theory. Where lynching rates were exceptionally high, we can expect that far larger African American proportions will be necessary before the number of death sentences start to decline. Increases in African American political influence should be obstructed in these states with high lynching rates partly because larger black populations should be more threatening to whites, who probably will take additional steps to resist black political influence in such jurisdictions.

\section{ALTERNATIVE EXPLANATIONS FOR DEATH SENTENCES}

The United States is an exceptionally direct democracy, so voters decide policies that are controlled by unelected officials elsewhere (Savelsberg 1994). Such arrangements enhance the effects of public values, particularly when an intensely moral outcome such as the death sentence is decided (Windlesham 1998). The judicial politics literature suggests that public opinion influences the courts (Carp and Stidham 1996; Hughes 1995) in part because all prosecutors and most trial court judges are elected. Because political and religious ideologies and partisanship affect death sentences (Jacobs and Carmichael 2004), these accounts should be examined as well. criminals as responsible for their acts. If "crime is a decision, not a disease" (John Major, quoted by Garland 2001), increases in the expected costs of such acts should be effective, so conservatives often believe that deterrence is the best antidote for crime. Conservatives use such rationales to justify dubious claims that the threat of the death chamber will save many innocent victims from criminal violence. ${ }^{4}$ But liberals believe that crime is caused by inequitable conditions (Garland 2001), so they are skeptical about harsh sanctions (Brillon 1988; Langworthy and Whitehead 1986). Capital punishment is likely to be legal in the most conservative states (Jacobs and Carmichael 2002). Hence, we expect more death sentences where conservative values dominate.

Fundamentalism. Religious conservatives stress retribution for crime. Historical studies show that religious views have helped to shape criminal punishments (Erikson 1966; Savelsberg 2004). Attitudinal results show that fundamentalist values are associated with enhanced support for severe criminal measures (Grasmick and McGill 1994; Grasmick et al. 1992). Where fundamentalism is strongest, prosecutors should be more likely to ask for the death penalty, and judges and juries should be sympathetic. Hence, death sentence frequencies should be greater in states with the most fundamentalist church memberships. Religion, of course, can affect attitudes without altering legal decisions (Jacobs and Carmichael 2002), so this hypothesis should be tested.

JudiCIAL SELECTION. Death sentences should be more likely where judges must face the voters. Lenient judges who ignore the substantial public support for capital punishment and block death sentences should be particularly vulnerable in states that use partisan judge elections (Brace and Hall 1997; Bright and Keenan 1995). Although Blume and Eisenberg (1999) found no

\footnotetext{
${ }^{4}$ Careful reviews of the multiple empirical studies on this issue conducted by legal scholars (Zimring and Hawkins 1986), a criminologist (Paternoster 1991), sociologists (Bailey and Peterson 1999), and an economist (Levitt 2002) conclude that the death penalty has no discernable general deterrent effects beyond those conferred by long prison terms.
} 
evidence that judicial elections produce added death sentences, Hall (1992) reported that appellate justices were less likely to rule against death penalty verdicts in states with short judicial election terms. Huber and Gordon (2004) reported that felony sentences became more severe as a judge's time to his or her next election diminished. Partisan elections inhibit judicial independence (Hanssen 2004), so death sentences should be more common if judges face partisan elections.

PARTISANSHIP. Criminal punishment is inherently political. In contrast to rivals to their left, findings show that conservative parties support harsh punishments (Jacobs and Carmichael 2001; Stucky, Heimer, and Lang 2005; Sutton 2000). Law and order campaign appeals have helped Republicans win elections (Edsal and Edsal 1991). Capital punishment is likely to be legal where Republican strength is greatest (Jacobs and Carmichael 2002), and more death sentences occur in such states (Jacobs and Carmichael 2004). Hence, death sentences should be increasingly likely in states with a Republican governor because of the sensitizing effects of Republican rhetoric (Beckett 1997), and because the success of such law and order candidates indicates greater support for harsh punishments.

Additional CONTROLS. Research on legal punishment has focused on the neo-Marxist hypothesis that punishment is used to control the excess supply of labor in capitalist societies (Rusche and Kirchheimer 1939). Many studies have assessed the link between unemployment and incarceration, but the results have been inconsistent. One review has shown that only about 60 percent of the 147 associations between unemployment and imprisonments were significant and positive (Chiricos and Delone 1992). Despite such mixed findings, we expect that high joblessness rates will increase death sentences because the prosperous may view the unemployed as a threat to the social order (Chambliss 1964), or because substantial unemployment produces greater resentments against street criminals and magnifies demands for severe punishments.

Violent crime rates must be held constant because death sentences should be frequent in jurisdictions that experience more of these crimes. Rankin (1979) detected a positive relationship between violent crime rates and support for the death penalty. Jurisdictions with the highest violent crime rates therefore should be more likely to use the death sentence after the number of capital crimes has been held constant. High property crime rates also may enhance perceptions of threat and produce successful public demands for more death sentences. In the statistical analyses, we control for each of these potential influences, but our primary focus is on the combined relationship between prior lynchings, current racial threat, and death sentences.

\section{METHODS}

\section{RESEARCH DESIGN, THE DEPENDENT VARIABLE, AND ESTIMATION}

Death sentences are unusual, so apparently no existing offender level court data sets provide the information required for a statistical study of this sentence..$^{5}$ The factors that produce death sentences must be assessed with an analysis of state counts. This unit of analysis is appropriate because state governments help to determine death sentence frequencies in important ways. These governments specify the number of jurors and hence the difficulties prosecutors face when they must obtain unanimous verdicts. The states decide whether prosecutors can depart from rules of evidence during the final sentencing phase in capital trials (see note 1), whether judges stand for election, and whether these elections are partisan. These governments also stipulate the list of aggravating and mitigating factors that juries must consider in the separate sentencing stage of capital trials.

${ }^{5}$ Bureau of Justice data on all felony convictions in five death penalty states show that only about 2 of 1,000 offenders received this sentence, but these five states were more likely to impose this sentence than other death penalty states. The paucity of death sentences and other data limitations make a general analysis of the contextual conditions that produce variation in death sentences impossible with individual sentencing data. Because individual data on the race of victims are unavailable, we can only guess about the results of an analysis that could take this factor into account. 
Except for lynchings, in the primary analyses we use explanatory variables in 1970, 1980, and 1990 to explain death sentence counts in states in 1971-1972, 1981-1982, and 1991-1992. Inclusion of periods separated by multiple years in a pooled time-series design substantially reduces serial correlation and the effects of measurement error (Johnston and DiNardo 1997). Because the main estimator we use cannot eliminate serial correlation, we limit this analysis to these three separated periods. We begin with 1970 because data on several important explanatory variables are not available before then. In the primary analyses, death sentences and African American death sentences in each of these three 2-year sets are summed to reduce the proportion of states with no death sentences and to reduce volatility. By summing death sentences in such large aggregates over three 2-year periods, idiosyncratic events are less likely to distort the findings. Although there have been well-publicized exceptions, death sentences result from an elaborate legal process designed to rule out capricious effects (see note 1 ). ${ }^{6}$ Because the racial conflicts based on slavery had little or no effects on Alaska and Hawaii, and because both states had idiosyncratic race relations in part because of their extremely modest black populations, we eliminate these states, leaving 144 stateyears in the primary analyses.

Tolnay and Beck (1996), however, claimed that the only available national data on lynchings are inaccurate. These authors painstakingly enumerated lynchings, but they counted these events in only 10 southern states. To discover whether the same results persist when the Tolnay and Beck data are used in place of the counts of lynchings in all states by the National

${ }^{6}$ The federal courts overturn many death sentences. The state courts that void more death sentences cannot disregard federal rulings, but the federal courts are not subject to state law, so their decisions cannot be modeled with state level explanatory variables. Since 1972, mean state delays from first death sentence to execution ranged from about 4.5 years (Nevada) to about 16 years (California, Nebraska). These delays have lengthened since 1972, so mean time on death row before execution often exceeds 20 years. In addition to difficulties stipulating appropriate lags, other problems make a plausible, purely state level execution analysis unlikely.
Association for the Advancement of Colored People (NAACP), we provide additional pooled time-series analyses that assess almost identical models using yearly contiguous data from 1970 to 1990 from these 10 states. In these analyses based on these 210 state-years, we can correct for serial correlation, so this temporally contiguous data will not threaten the findings.

Estimation. Because death sentences are infrequent, and because there are important reasons for avoiding rates in analyses of rare events (Osgood 2000), we use a specialized statistical procedure designed to estimate unusual occurrences (Cameron and Trivedi 1998). Ordinary Least Squares provides inconsistent estimates when there are many zero-limit scores in a count-dependent variable with a modest mean, but dedicated count estimators are consistent (Cameron and Trivedi 1998; Long 1997). ${ }^{7}$ We estimate all models with negative binomial instead of a Poisson approach because statistical tests show that overdispersion is present.

In the 48-state analyses, death sentences may not occur either because capital punishment was illegal in a state or because this punishment was legal, but state trial courts did not impose death sentences. Yet selection bias might be present if we confine this analysis only to states with a legal death penalty. To handle this difficulty, we analyze all 144 state-years, but estimate with a zero-inflated negative binomial procedure (Cameron and Trivedi 1998; Long 1997) that uses two equations. One equation estimates the factors that produce zero scores and the other equation detects the factors that produce one or more death sentences. Zeroinflated estimation is appropriate if the popu-

\footnotetext{
${ }^{7}$ The few death sentences mean that this outcome is best analyzed as a count because rates computed on rare events are unstable. One historically unique death sentence in a small state can cause a dramatic shift from zero to a high rate, so small state variances often exceed large state variances in rates. These instabilities produce heteroskedasticity (Osgood 2000). The zero-inflation approach produces more stable estimates than attempts (not shown) to overcome selection problems with Heckman procedures. We use the Stata version 7 "zinb" procedure for zeroinflated models and this program's "xtgee nbreg" procedure to estimate count models.
} 
lation is divided into two subgroups, with one subgroup never at risk of the outcome at issue (Cameron and Trivedi 1998:128). The zero category of a count-dependent variable should contain a mix of cases, with some cases at risk and others not at risk (Cameron and Trivedi 1998). If capital punishment is illegal, offenders cannot be sentenced to death. An absence of death sentences thus could be attributable to either a failure to legalize this punishment or a failure to impose the death sentence although it is legal. These two reasons for no death sentences fit the mixture condition required for zero-inflated estimation perfectly.

Additional explanatory variables in statistical models produce less efficient estimates (Johnston 1984), and there is no reason to include the same variables in the primary and secondary equations of zero-inflated models (Long and Freese 2001). Adding variables to the secondary equations that explain zero death sentences does not enhance explanatory power. We therefore use parsimonious but empirically powerful specifications based on findings about the legality of capital punishment (Jacobs and Carmichael 2002) in these secondary equations. We handle the fact that observations from the same state during these three periods are unlikely to be independent by correcting the standard errors for the probable interdependence between same-state scores over time. This cluster correction produces less efficient but more robust standard error estimates than those from a dedicated panel estimator (Rogers 1993). Zero-inflated models therefore let us retain the states without the death penalty and avoid selection bias at the potential cost of marginally larger standard errors, but this cost apparently is minimal.

In contrast to the 48-state analyses, capital punishment was legal in the great majority of state-years in the analysis restricted to the 10 southern states that use the Tolnay and Beck (1996) lynching counts. It follows that the proportion of state-years with no death sentences is considerably lower in these analyses than this proportion in the 48-state analyses. These 10state models therefore can be estimated with a conventional single-equation negative binomial panel approach. We use the population-averaged, random-effects estimator in these analyses because this approach can correct for serial correlation and heteroskedasticity.

\section{EXPLANATORY VARIABLE MEASUREMENT}

One type of minority presence and racial threat is gauged with both continuous and threshold measures of the percentage of blacks. Findings show that a dummy variable threshold measure of black presence has the greatest explanatory power when the legality of the death penalty is at issue (Jacobs and Carmichael 2002). Because it produces the most substantial effects in the secondary equations that predict the absence of death sentences, we follow this precedent and report models with a dummy variable scored 1 if the percentage of blacks in a state is greater than the state median ( 6.4 percent). Yet because black presence is a component of the interaction term, we use the percentage of blacks in the primary equations designed to explain death sentence counts. Another form of minority presence is assessed with the percentage of Hispanics.

In the 48-state analyses, we compute lynching rates with the NAACP data on state lynchings from 1889 to 1931 divided by mean state populations in this period. In the analysis of 10 southern states, we use the Tolnay and Beck (1996) statistics to compute these rates. The percentage of African Americans and the lynching rates are mean centered before they are multiplied to create the interaction term. In models that gauge interaction effects, the coefficient on a mean-centered main effect represents this variable's additive contribution when the alternative mean-centered main effect is equal to its mean. If mean centering is not used, the coefficient on each main effect shows the additive relationship between that main effect and the dependent variable when the value of the alternative main effect is zero. Centering makes theoretical sense because the racial threat hypothesis we test suggests that prior lynchings in a state are not likely to produce more death sentences if there are no current black residents in the state. This procedure is methodologically useful as well because it helps to reduce collinearity between main effects and the interaction term (Cohen et al. 2003).

Berry et al. (1998) viewed public political ideologies as the mean position on a liberal-conservative continuum. They identified the ideological position of each member of Congress with interest group ratings (Americans for Democratic Action, Committee on Political Education) of that representative's voting record. They estimated public ideology within each 
congressional district with the ideology score for the district's incumbent and an estimated score for that incumbent's challenger in the last election. Incumbent ideology scores are combined with estimated challenger ideology scores weighted by within-district election results to capture district ideologies. Berry et al. (1998) calculated state scores on liberalism-conservatism using the mean of these within-state congressional district scores, with the most liberal states receiving the highest scores.

We assess fundamentalism with a scale created by Morgan and Watson (1991) that is based on the percentage of residents who are members of fundamentalist churches. This scale is available only for 1980, but Newport (1979) suggested that church affiliations in large aggregates such as states are extremely stable. We capture the threat attributable to crime with Uniform Crime Rate violent and property crime rates, and we control for capital offenses by entering the number of state murders. We use crime rates to gauge this menace in states with different populations. The number of violent or property crimes would be inappropriate because the great majority of crimes are not capital offenses. We use the number of murders rather than the rates to capture the number of offenders at risk for the death penalty. ${ }^{8}$ Judge selection is measured with a dummy variable coded 1 for partisan elections using data supplied by Hanssen (2004), and unemployment is measured with decennial Census rates. Population and its square are included to adjust for the likelihood that the number of death sentences will be greater in the most populated states yet this relationship may not be linear. In the models that assess the determinants of black death sentences, we instead use the number of African Americans and its square. In the primary analyses, dummy variables for two of the three

\footnotetext{
${ }^{8}$ Before 1970, the federal courts forbade the death sentence for rape. With the exception of quite unusual murders, no other violent crimes could result in a state death sentence during the sample period. Violent crimes therefore should be in rate rather than count form. The media focuses on rates, so higher violent crime rates should accentuate public anxieties. Substantial violent crime rates should produce greater media-induced apprehension and heightened public demands for harsh punishments.
}

periods are included in the models to capture cross-state trends and regional dummies are entered to capture otherwise unmeasured factors such as culture.

The prior discussion suggests that the ideology index, which gives liberal states a higher score, should be inversely related in the equation that explains multiple death sentences. The coefficients on all the remaining explanatory variables should be positive in the first equation that predicts death sentence counts equal to or greater than one. The second equation predicts the probability of a zero score, or the absence of death sentences (Long 1997:245-46; Long and Freese 2001), so we expect opposite signs on the coefficients on theoretically relevant explanatory variables in this equation. We do not predict the signs of region, year, or the intercepts, so two-tailed tests are used to assess these effects. All other relationships are gauged with one-tailed significance tests.

\section{SPECIFICATION}

One of the more general specifications of the primary zero-inflated negative binomial equation that models integer counts of one or more death sentences therefore is as follows:

$$
\begin{gathered}
\text { N death sentences }= \\
\mathrm{b}_{0}+\mathrm{b}_{1}(\% \text { black } \times \text { lynch rate })+ \\
\mathrm{b}_{2} \text { lynch rate }+ \\
\mathrm{b}_{3} \% \text { black }+\mathrm{b}_{4} \% \text { black }{ }^{2}+\mathrm{b}_{5} \text { ideology }+ \\
\mathrm{b}_{6} \text { violent crime rate }+ \\
\mathrm{b}_{7} \text { property crime rate }+\mathrm{b}_{8} \mathrm{~N} \text { murders }+ \\
\mathrm{b}_{9} \text { south }+\mathrm{b}_{10} \% \text { unemployed }+ \\
\mathrm{b}_{11} \text { population }+\mathrm{b}_{12} \text { population }{ }^{2}+ \\
\mathrm{b}_{13} 1980+\mathrm{b}_{14} 1990+\mathrm{b}_{15} \% \text { Hispanic }+ \\
\mathrm{b}_{16} \text { fundamentalism }+\mathrm{b}_{17} \% \text { unemployed }+ \\
\mathrm{b}_{18} \text { partisan judge election, }
\end{gathered}
$$

where $\mathrm{N}$ death sentences is one or more death sentences in a state during the 2 years after each of the 3 census years.

Because the results show that concise specifications have greater explanatory power than alternatives, and because there is no statistical reason to include the same explanatory variables in the second equation, which predicts the probability of zero death sentences (Long 
and Freese 2001), these secondary equations will be parsimonious. One of the more general specifications of the equation that predicts zero death sentences therefore is as follows:

$$
\begin{gathered}
\text { death sentence absence }= \\
\mathrm{b}_{0}+\mathrm{b}_{1} \text { \%black }+\mathrm{b}_{2} \text { ideology }+ \\
\mathrm{b}_{3} \text { republican government }+ \\
\mathrm{b}_{4} \text { South }+\mathrm{b}_{5} \text { West }+\mathrm{b}_{6} \text { Midwest }+ \\
\mathrm{b}_{7} 1980+\mathrm{b}_{8} 1990 .
\end{gathered}
$$

\section{ANALYSES}

\section{VARIABLE DISTRIBUTIONS AND A CROSS- TABULATION}

Table 1 shows the expected signs along with the means and standard deviations both across states and over time. To give readers an intuitive picture of the death penalty distribution in categories of the two most important explanatory variables, Table 2 shows the mean number of death sentences cross-classified by the percentage of African Americans in the states and by the number of lynchings. The counts in the cells on the downward diagonal suggest that death sentences sharply increase as state scores on the two primary explanatory variables become greater. Such contrasts suggest that death sentence frequencies were greater in states with the most black residents and lynchings. ${ }^{9}$ These comparisons also imply that an interaction effect may be present because death sentence counts in the bottom right cell are substantially larger than their counterparts in adjacent cells. Of course, these differences may not persist after other factors are held constant in more sophisticated analyses, but they suggest that additional empirical support for the explanations that motivated this inquiry would not be an artifact of the sophisticated count procedures we use in the main analyses.

\section{ZERo-INFLATED ANALYSES OF 48 STATES}

The results from the zero-inflated count models, which explain all death sentences and death sentences given to blacks, are presented in Table 3. The first two models show the results when the total number of death sentences is at issue. We begin with a restricted model (Model 1). In Model 2 we add the percentage of Hispanics, the property crime rates, and the judge election

\footnotetext{
${ }^{9}$ States with the largest number of death sentences tend to be in the South. Only Indiana and Missouri are exceptions. States that have used this sentence least include northern states such as Connecticut,

\begin{tabular}{|c|c|c|c|c|c|}
\hline Variable & Predicted Sign & Mean & $\begin{array}{l}\text { Overall } \\
\text { SD }\end{array}$ & $\begin{array}{c}\text { Cross-State } \\
\text { SD }\end{array}$ & $\begin{array}{c}\text { Over-Time } \\
\text { SD }\end{array}$ \\
\hline Death Sentences (n) & & 8.410 & 15.604 & 12.557 & 9.382 \\
\hline Black Death Sentences (n) & & 3.590 & 6.995 & 5.586 & 4.262 \\
\hline Lynch Rate & + & .046 & .066 & .066 & .000 \\
\hline Black (\%) & + & 9.416 & 9.269 & 9.308 & .701 \\
\hline Liberalism-Conservatism Index & - & 44.34 & 15.65 & 14.52 & 6.10 \\
\hline Violent Crime Rate & + & 417.5 & 254.6 & 213.5 & 141.0 \\
\hline Property Crime Rate & + & $3,887.7$ & 1678.7 & 967.9 & 1376.3 \\
\hline Murders (n) & + & 425.2 & 603.4 & 577.9 & 186.4 \\
\hline Population & + & 4.670 & 4.876 & 4.840 & .822 \\
\hline Black (n) & + & 53,841 & 63,130 & 62,640 & 10,792 \\
\hline Hispanic (\%) & + & 4.381 & 7.086 & 7.030 & 1.220 \\
\hline Religious Fundamentalism & + & .216 & .228 & .230 & .000 \\
\hline Unemployed (\%) & + & 5.983 & 1.641 & 1.152 & 1.176 \\
\hline 1 if Republican Governor & + & .444 & .499 & .294 & .404 \\
\hline
\end{tabular}
the Dakotas, Idaho, Massachusetts, Montana, Nebraska, New Hampshire, Vermont, Washington, and Wyoming.
}

Table 1. Variable Means, and Standard Deviations Across States and over Time

Note: Data based on 144 state-years; expected signs are opposite in secondary equations that predict zero death sentences. $\mathrm{SD}=$ standard deviation. 
Table 2. Mean Number of Death Sentences Cross-Classified by Percentage of Blacks and by Number of Lynchings in 48 States

\begin{tabular}{lcccc}
\hline \hline & \multicolumn{4}{c}{ Lynchings } \\
\cline { 2 - 5 } Percentage of Blacks & Few & Intermediate & High & Row Totals \\
\hline Low & .04 & 4.76 & 1.00 & 1.82 \\
& $(24)$ & $(17)$ & $(9)$ & $(50)$ \\
Intermediate & 5.88 & 12.16 & 9.00 & 9.23 \\
& $(16)$ & $(19)$ & $(9)$ & $(44)$ \\
High & .63 & 11.07 & 20.11 & 14.28 \\
& $(8)$ & $(15)$ & $(27)$ & $(50)$ \\
Column Totals & 2.08 & 9.37 & 14.07 & $(45)$ \\
& $(48)$ & $(51)$ &
\end{tabular}

Note: Analysis based on 144 state-years; state-year cell counts are in parentheses.

$p \leq .0001($ ANOVA F-test $=6.59)$.

variable, but the variables included in the secondary equation that explain the absence of any death sentences remain unchanged. Models 3 and 4 in Table 3 show what happens when we use almost identical models to explain death sentences given to African Americans. The only difference between the right side of these two models and their prior counterparts that explained all death sentences is our use of the number of African Americans and its square rather than total state populations.

The results based on the first pair of equations, which together constitute Model 1, show that the interaction between African American presence and prior lynchings explains state propensities to use the death sentence one or more times. Expectations based on Blalock's version of threat theory are supported as well. The relationship between black presence and death sentence frequencies departs from linearity (the exact form of these nonlinear interactive relationships is explored graphically; see later in the section on zero-inflated analyses of 48 states).

The findings support another threat hypothesis because they suggest that jurisdictions with higher violent crime rates are more likely to use this sentence after the number of murders has been held constant. Fundamentalist church memberships also have positive effects in this analysis of all death sentences. The results for the second equation in Model 1, which predicts zero death sentences, support prior findings about the legality of this punishment (Jacobs and Carmichael 2002). They show that jurisdictions with black populations larger than the state median are more likely to use this sentence at least once. The results in Model 2 are almost identical to those reported in Model 1. Both models suggest that the joint effects of lynchings and black threat lead to additional death sentences, a finding that supports the primary theoretical supposition that prompted this research.

Models 3 and 4 depict the results when black death sentences are analyzed. To capture the population at risk of these death sentences, the number of African Americans replaces the total population in Models 3 and 4, but that substitution and the dependent variable are the only differences between Models 1 and 2 and Models 3 and 4. As might be expected, because the dependent variable is restricted to African American death sentences, the nonlinear relationship between the percentage of African Americans and death sentences now is stronger and has more consistent effects in these analyses. ${ }^{10}$ In contrast to the results when all death sentences were at issue, the unemployment rates explain black death sentences, but there is no

\footnotetext{
${ }^{10}$ In part because these relationships are both nonlinear and interactive, the important factor is the degree to which both nonlinear terms are jointly significant. These paired terms are significant in Models 3 and 4 in Table 4 . The point where the relationship between the percentage of blacks and death sentences shifts from positive to negative cannot be determined with the formula that is appropriate for noninteractive quadratic relationships. Instead, this nonlinear relationship and its dependence on lynching rate values will be illustrated graphically.
} 
Table 3. Number of Death Sentences in the States in 1971-1972, 1981-1982, and 1991-1992

\begin{tabular}{|c|c|c|c|c|}
\hline \multirow{3}{*}{1 or more Death Sentences } & \multicolumn{2}{|c|}{ All Death Sentences } & \multicolumn{2}{|c|}{ Black Death Sentences } \\
\hline & Model 1 & Model 2 & Model 3 & Model 4 \\
\hline & & & & \\
\hline \multirow{2}{*}{ Lynch rate $\mathrm{x}$ Percent Black } & $.367 *$ & $.352 *$ & $.969 *$ & $.989 *$ \\
\hline & $(.159)$ & $(.169)$ & $(.449)$ & $(.477)$ \\
\hline \multirow{2}{*}{ Lynch rate (centered) } & -2.439 & -1.949 & -6.834 & -6.933 \\
\hline & $(1.766)$ & $(1.880)$ & $(4.413)$ & $(4.493)$ \\
\hline \multirow[t]{2}{*}{ Percent Black (centered) } & -.012 & .009 & .014 & .028 \\
\hline & $(.032)$ & $(.052)$ & $(.048)$ & $(.057)$ \\
\hline \multirow[t]{2}{*}{ Percent Black ${ }^{2}$ (centered) } & -.002 & -.003 & $-.007 * *$ & $-.008 * *$ \\
\hline & $(.002)$ & $(.003)$ & $(.003)$ & $(.003)$ \\
\hline \multirow[t]{2}{*}{ Liberal-Conservative Index } & -.013 & -.010 & -.011 & -.010 \\
\hline & $(.011)$ & $(.012)$ & $(.009)$ & $(.011)$ \\
\hline \multirow[t]{2}{*}{ Number of Murders } & -.000 & -.000 & .000 & .000 \\
\hline & $(.000)$ & $(.000)$ & $(.000)$ & $(.000)$ \\
\hline \multirow[t]{2}{*}{1 if South } & .080 & -.055 & .277 & .210 \\
\hline & $(.305)$ & $(.469)$ & $(.447)$ & $(.480)$ \\
\hline \multirow[t]{2}{*}{ Population or Number of Blacks $/ 10^{3}$} & $.232 * * *$ & $.229 * * *$ & $.002 * *$ & $.002 * *$ \\
\hline & $(.041)$ & $(.047)$ & $(.001)$ & $(.001)$ \\
\hline \multirow[t]{2}{*}{ Population $^{2}$ or Number of Blacks ${ }^{2} / 10^{8}$} & $-.445 * * *$ & $-.428 * * *$ & $-.009 * *$ & $-.009 * *$ \\
\hline & $(.107)$ & $(.105)$ & $(.004)$ & $(.003)$ \\
\hline \multirow[t]{2}{*}{1 if 1980} & $1.049 * *$ & $.944^{*}$ & .532 & .386 \\
\hline & $(.370)$ & $(.482)$ & $(.341)$ & $(.525)$ \\
\hline \multirow[t]{2}{*}{1 if 1990} & $.861 * *$ & .791 & .399 & .279 \\
\hline & $(.349)$ & $(.415)$ & $(.439)$ & $(.583)$ \\
\hline \multirow{2}{*}{ Religious fundamentalism } & $1.914 * *$ & $2.162 *$ & .984 & 1.185 \\
\hline & $(.805)$ & $(1.145)$ & $(.722)$ & $(.881)$ \\
\hline \multirow[t]{2}{*}{ Percent Unemployed } & .105 & .105 & $.161^{*}$ & $.177 *$ \\
\hline & $(.086)$ & $(.100)$ & $(.093)$ & $(.101)$ \\
\hline \multirow[t]{2}{*}{ Violent crime rate } & $.002 * *$ & $.001 *$ & $.002 *$ & $.002 *$ \\
\hline & $(.001)$ & $(.000)$ & $(.001)$ & $(.001)$ \\
\hline Property crime rate & - & .000 & - & .000 \\
\hline & & $(.000)$ & & $(.000)$ \\
\hline Percent Hispanic & - & .008 & - & .006 \\
\hline & & $(.036)$ & & $(.028)$ \\
\hline 1 if Partisan judge elections & - & -.169 & - & -.180 \\
\hline & & $(.388)$ & & $(.412)$ \\
\hline Intercept & -1.064 & $-1.087^{*}$ & $-1.883 *$ & $-1.933^{*}$ \\
\hline & $(.584)$ & $(.521)$ & $(.934)$ & $(.969)$ \\
\hline Death Sentence Absence & & & & \\
\hline 1 if Percent Black $\geq$ median & $-3.354 * * *$ & $-3.313 * * *$ & $-4.333^{*}$ & $-4.238 *$ \\
\hline & $(1.053)$ & $(1.094)$ & $(1.873)$ & $(1.923)$ \\
\hline Liberal-Conservative Index & .117 & .128 & $.184 *$ & $.186^{*}$ \\
\hline & $(.151)$ & $(.196)$ & $(.089)$ & $(.087)$ \\
\hline 1 if Republican Governor & -1.323 & -1.436 & $-2.482 *$ & $-2.507^{*}$ \\
\hline & $(1.265)$ & $(1.959)$ & $(1.297)$ & $(1.191)$ \\
\hline 1 if South & -2.250 & -2.333 & -2.541 & -2.690 \\
\hline & $(1.288)$ & $(1.336)$ & $(1.588)$ & $(1.644)$ \\
\hline 1 if West & -3.292 & -3.361 & -.921 & -.880 \\
\hline & $(2.371)$ & $(2.990)$ & $(2.115)$ & $(2.057)$ \\
\hline 1 if Midwest & .138 & .335 & 2.111 & 2.135 \\
\hline & $(2.708)$ & $(3.701)$ & $(2.264)$ & $(2.107)$ \\
\hline 1 if 1980 & .651 & .854 & 1.162 & 1.176 \\
\hline & $(2.552)$ & $(3.937)$ & $(1.226)$ & $(1.059)$ \\
\hline 1 if 1990 & -.748 & -.629 & -.624 & -.663 \\
\hline & $(1.895)$ & $(2.479)$ & (1.314) & $(1.241)$ \\
\hline Intercept & -2.959 & -3.751 & -6.377 & -6.568 \\
\hline & $(9.969)$ & $(13.457)$ & $(4.854)$ & $(4.541)$ \\
\hline Log likelihood & -293.8 & -293.3 & -208.7 & -208.4 \\
\hline
\end{tabular}

Note: Data shown are coefficients with standard errors in parentheses. Zero-inflated negative binomial estimates of the number of black death sentences. Analysis based of 144 state-years; within state cluster corrected standard errors.

a Total state population is entered in Models 1 and 2; the Black population is entered in Models 3 and 4.

$* p \leq .05 ; * * p \leq .01 ; * * * p \leq .001$ (one-tailed tests except for intercepts, region, and years). 
evidence that religious fundamentalism leads to additional death sentences for blacks.

The only other findings that depart from those in the first two models appear in the secondary equations, which predict the complete absence of black death sentences. These results suggest that political effects matter in these restricted analyses, because the findings suggest that a complete absence of black death sentences is unlikely in states with a Republican governor and those in which conservative views are dominant. ${ }^{11}$

To give the reader an intuitive picture of these combined nonlinear and interactive effects,

11 The statistical significance of the interaction term is not sensitive to the removal of additional explanatory variables in these models. For example, elimination of the squared term that captures the population at risk of a death sentence or the fundamentalism measure does not alter these results. Models that include a dummy coded 1 if the death penalty is legal in the secondary equations that predict the absence of death sentences are too collinear to be estimated.
Figure 1 graphs the predicted number of African American death sentences based on the coefficient on the interaction term and the coefficients on the quadratic terms that assess the nonlinear relationship between the percentage of blacks and the number of black death sentences using point estimates from Model 4 in Table 3. Because these associations are interactive, the relationship between African American presence and the number of their death sentences should differ depending on lynching rate values. To illustrate these conditional contrasts, we graph two relationships. The first shows the predicted association between the percentage of blacks and black death sentences, with lynching rates equal to the 25 th percentile (this relationship is horizontally truncated because of limits on the percentage of blacks in states with so few lynchings). The second to the right of the first relationship shows this nonlinear association in jurisdictions with lynching rates at the 95 th percentile.

As shown earlier, predictions derived from theories at issue suggest that in states with high lynching rates, it should take a far larger African

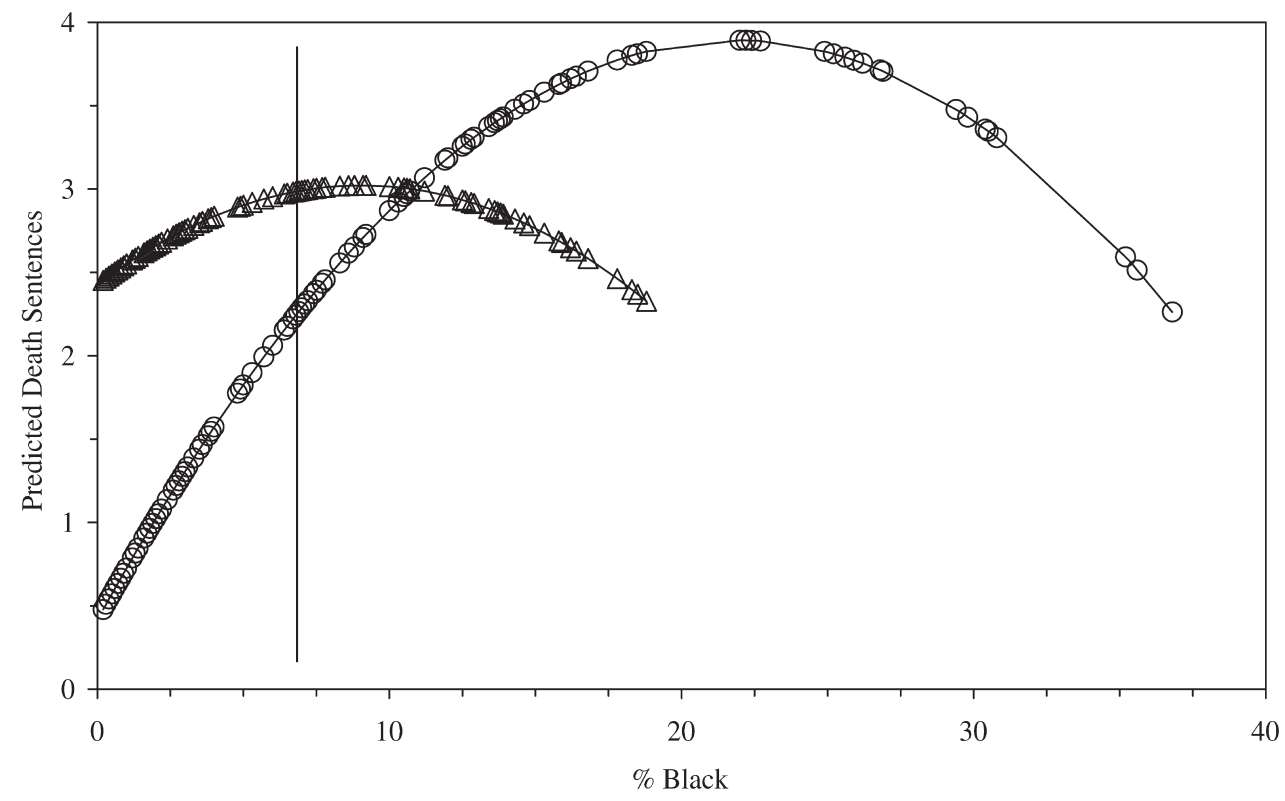

$\triangle$ Lynch Rate, 25th Percentile $\quad-$ Lynch Rate, 95th Percentile

Figure 1. Relationships between the Percentage of Blacks and Predicted Death Sentences When Lynchings Are at the 25th Percentile and When Lynchings are at the 95th Percentile

Note: Vertical line denotes the median percentage of blacks in the 48 states. 
American presence before the number of death sentences begins to fall as a consequence of increased black populations. This is so because the threat attributable to larger black populations should be more menacing to whites in these jurisdictions. Hence, white resistance to black political influence should be greater in such states. Figure 1 implies that this expectation is correct because the inflection point at which the relationship between the percentage of African Americans and the number of African American death sentences shifts from positive to negative materializes only after the percentage of African Americans exceeds 20 percent in the states with a high lynching rate (the vertical line denotes the median percentage of blacks to highlight these differences in the location of inflection points on the horizontal axis). The contrasts in this graph are revealing because they clearly show how racial threat had a stronger influence on African American death sentences in states in which vigilante violence, largely directed against this racial minority, was most pronounced. ${ }^{12}$

\section{ANALYSES OF IO SOUTHERN STATES}

Yet it is possible that the 48 -state results are biased by measurement error in the NAACP lynching data (Tolnay and Beck 1996). The only available alternative counts were enumerated by Tolnay and Beck, but these counts are restricted to lynchings in 10 southern states. ${ }^{13}$ We nevertheless can check the prior findings with models computed on this 10-state lynching data, but we must include all state-years between 1970 and 1990 to provide sufficient

${ }^{12}$ Because the other explanatory variables are not held at their means, the vertical placement of the two relationships shown in Figure 1 is arbitrary, but the contrasts between the two estimated relationships depicted in this graph are meaningful. The horizontal differences in inflection point placement across the $\mathrm{x}$ axis and the vertical differences in the location of these two inflection points on the y axis reflect estimated relationships based on the data. Attempts to find nonlinear relationships between lynchings and death sentences were unsuccessful.

${ }^{13}$ The 10 states included in these analyses because alternative Tolnay and Beck (1996) counts of lynchings are available are Alabama, Arkansas, Florida, Georgia, Kentucky, Louisiana, Mississippi, North Carolina, South Carolina, and Tennessee. cases. We now estimate with a panel-corrected negative binomial rather than a zero-inflation approach. Zero death sentences occurred in only a few state-years in this sample largely because this penalty almost always was legal in these states. It follows that zero-inflated estimation is unnecessary in these models, and Vuong test results support this conclusion. Yet because we must use contiguous years, serial correlation may be problematic. To correct this problem, we estimate with a population-averaged, random-effects approach.

Table 4 presents two models. The first analyzes all death sentences, and the second assesses the determinants of the number of African American death sentences. Because this sample is restricted to a region in which racial effects should differ from those in the 48-state analyses, some model respecifications are appropriate. In these 10-state analyses, we test a few additional quadratic relationships because the influence of threat effects based on higher violent crime rates, murders, and the presence of another minority (Hispanics) should be stronger in states that have such an idiosyncratic history of violent racial conflicts.

It is noteworthy that the two 10-state analyses reported in Table 4 support the prior findings based on the NAACP lynching counts. The only contrasts between these 10 -state results and those based on 48 states concern a few additional departures from linearity. As expected from threat theory, after the number of murders and the percentage of Hispanics reach modest thresholds in these southern states, the relationships between such threats and death sentences become increasingly positive. But the main implication of these new models is that results based on different lynching counts and a different sample support the 48-state findings. The interaction between current black presence and past vigilante violence explains death sentence frequencies in both the 48-state and the 10-state analyses. We can conclude from this exercise that the 48-state findings probably cannot be attributed to measurement error in the NAACP lynching data.

ADDITIONAL TESTS. The zero-inflated models reported in Table 3 always pass the Vuong test, so this zero-inflation procedure is more appropriate than single-equation count estimators would be in the 48-state analyses. Additional 
Table 4. Number of All Death Sentences and Number of Black Death Sentences in Ten Southern States from 1970 to 1990

\begin{tabular}{lcccr}
\hline & \multicolumn{2}{c}{ All Death Sentences } & \multicolumn{2}{c}{ Black Death Sentences } \\
\hline Lynch Rate $\times$ Percent Black & $.489^{*}$ & $(.229)$ & $.618^{* *}$ & $(.260)$ \\
Lynch Rate (centered) & -.248 & $(1.935)$ & -2.493 & $(2.441)$ \\
Percent Black (centered) & .010 & $(.014)$ & -.022 & $(.034)$ \\
Percent Black ${ }^{2}$ (centered) & $-.003^{*}$ & $(.001)$ & -.002 & $(.002)$ \\
Liberal-Conservative Index & $-.018^{*}$ & $(.008)$ & $-.040^{* * *}$ & $(.011)$ \\
Violent Crime Rate & $.010^{* * *}$ & $(.003)$ & $.012^{* * *}$ & $(.003)$ \\
Violent Crime Rate $2 / 10^{5}$ & $-.853^{* * *}$ & $(.225)$ & $-.917^{* * *}$ & $(.213)$ \\
Property Crime Rate & .000 & $(.000)$ & .000 & $(.000)$ \\
Number of Murders & $-.004^{*}$ & $(.002)$ & $-.004^{*}$ & $(.002)$ \\
Number of Murders $/ 10^{5}$ & $.216^{* *}$ & $(.089)$ & $.247^{* *}$ & $(.104)$ \\
Percent Hispanic & $-.546^{* * *}$ & $(.103)$ & $-.384^{* *}$ & $. .165)$ \\
Percent Hispanic & $.048^{* * *}$ & $(.015)$ & $.057^{* * *}$ & $(.015)$ \\
Percent Unemployed & $.155^{* * *}$ & $(.020)$ & $.149^{* * *}$ & $(.022)$ \\
Population/10 & $.420^{6 * *}$ & $(.131)$ & - & - \\
Number of Blacks $/ 10^{6}$ & - & - & $.015^{*}$ & $(.007)$ \\
$\quad$ Intercept & $-2.422^{* * *}$ & $(.560)$ & $-2.126^{* *}$ & $(.728)$ \\
\hline
\end{tabular}

Note: Data shown are coefficients with standard errors in parentheses. Random-effects negative binomial estimates of the number of all death sentences and the number of Black death sentences. Analyses use the Tolnay and Beck Lynching Data (210 state-years; standard errors corrected for heteroskedasticity and serial correlation). $* p<.05 ; * * p<.01 ; * * * p<.001$ (one-tailed tests except for intercepts).

models (not shown) indicate that the same explanatory variables are influential after we remove the four state-years with the most death sentences. Such results suggest that the findings probably cannot be attributed to the influence of a few states with the highest death sentence counts. In other models (not shown), we find that economic indicators such as economic inequality, the poverty rate, and black-white income or unemployment ratios have no effects. If we instead use the percentage of blacks rather than a dummy variable when we assess the probability of no death sentences, the findings persist, but explanatory power is reduced. Hypotheses that threat measures work through partisanship or ideology to affect the number of death sentences are not supported. ${ }^{14}$ Additional statistical interactions do not explain death sentences, and attempts to use dummies to capture

${ }^{14}$ The conventional way to detect indirect effects involves path analysis, but this procedure is inappropriate in zero-inflated count analyses. A more defensible approach involves removing explanatory variables, but the results do not support hypotheses that some explanatory variables work through others to influence the number of death sentences. other threshold effects were equally unsuccessful.

The contrasts in death sentences when this outcome is cross-classified with black presence and lynchings plus the persistence of these results after we use diverse specifications, different samples, and different estimators imply that these findings represent the most important underlying processes determining death sentence frequencies. These results always suggest that states with the largest black populations and the most substantial inclinations to use vigilante violence in the past now are more likely to impose the death penalty. ${ }^{15}$

\section{CONCLUSIONS}

\section{RESULTS}

We find consistent support for the primary theoretical suppositions that prompted this analysis. If current death sentence frequencies are attributable in part to the combination of prior

${ }^{15}$ There is strong evidence that collinearity is not distorting the results. The primary difficulty imposed by collinearity is unstable coefficients. Yet the multivariate findings remain stable despite substantial changes in the specifications. 
illegal violence directed largely against blacks and the current racial threat based on the size of contemporary African American populations, an interaction term that assesses the joint effects of current racial threat and past vigilantism should have a positive relationship with recent death sentences. Our repeated findings that this relationship is present support claims that a prior tradition of lethal vigilantism enhances recent attempts to use the death penalty as long as the threat posed by current black populations is sufficient to trigger this legal but lethal control mechanism (Dollard 1957; Phillips 1987; Turk 1982).

The findings from secondary equations that predict zero death sentences show that states with percentages of blacks above a threshold are more likely to use the death sentence at least once. These results are based in part on a primary reason for the absence of this sentence. There can be no death sentences in states that do not have a legal death penalty. Past research finds that the death sentence is likely to be legal in states when the percentage of blacks is greater than the same threshold (Jacobs and Carmichael 2002). The current results support this finding by showing that an identical threshold has greater explanatory power than its continuous alternative when the complete absence of death sentences is at issue. Capital punishment, however, was legal in some states that never used the death sentence, so these secondary equations that predict zero death sentences capture both effects.

We find inconsistent support for the alternative minority threat hypothesis. Evidence that Hispanic threat matters can be found only in the southern state analyses. Such contrasting findings about the explanatory power of racial rather than Hispanic threat should not be surprising in light of the exceptionally divisive and violent conflicts about race throughout U.S. history (Myrdal 1944; Tocqueville [1835] 1948), which should give racial threat greater explanatory power than its Hispanic alternative. Yet because only a few states had substantial Hispanic populations before 1991, this ethnic group may not have been sufficiently large in enough states to trigger repressive responses. Subsequent studies therefore may support this ethnic threat account because the Hispanic population has expanded rapidly since 1990 .

The interaction between prior lynchings and black threat that predicted all death sentences offers modest support for a hypothesis that whites and blacks are more likely to receive this sentence in states with a vigilante tradition. Yet, as expected, the coefficients on this interaction term were stronger when the analyses were restricted to black death sentences. The findings in the models that analyze all death sentences nevertheless offer limited support for a supposition that past vigilantism leads to a legal system that makes the death penalty more likely for all offenders, even if this sanction is primarily designed to control black street criminals. One possible explanation for such findings concerns the need to avoid conspicuous discrimination in the death sentencing process. Frequent discrimination in this legal process that is undeniable would threaten the constitutionality of capital punishment. Unwarranted racial influences on this legal process probably must be subtle and difficult to detect if a legal death penalty is to be preserved. Although the evidence for this explanation for white death sentences could be more definitive, it is not contradicted by the inconsistent findings reported in the many studies on the effects of offender race on trial court decisions about the death sentence.

In light of Republican admissions that their law and order campaign appeals were designed to capture white votes (Beckett 1997), it is interesting that Republican control of the governor's office helps to explain the presence of at least one black death sentence, although Republican control of this office does not explain the total number of death sentences. As many political and social theorists (Garland 1990; Lacey 1988) would expect, we also find relationships between the strength of liberal political convictions and the complete absence of black death sentences. Both political findings are consistent with evidence about the legality of this punishment because past research has found that ideologically liberal states with weaker Republican parties were less likely to have a legal death penalty (Jacobs and Carmichael 2002).

Religious views account for all death sentences, but they do not explain the number of African American death sentences. These results nevertheless imply that prior findings about the relationship between fundamentalism and punitive views are not restricted to attitudes (Grasmick and McGill 1994; Grasmick et al. 1992). These links between fundamentalism 
and public support for harsh punishments also help to explain the imposition of the most severe sentence. Such findings about the links between political and religious conservatism and the greater use of the death sentence provide added support for theoretical claims about the effects of public values (Garland 1990, 2001; Savelsberg 1994; Windlesham 1998), particularly in a direct democracy such as the United States, when the most severe criminal sanction is decided.

Other threat findings are noteworthy. After the number of capital offenses and many additional factors have been held constant, we always find that jurisdictions with the highest violent crime rates are likely to sentence capital offenders to death. Such results are supported by findings showing that a positive relationship exists between violent crime rates and public support for the death penalty (Rankin 1979). Yet our results go further because they suggest that the menace produced by non-capital violent offenses also leads to a greater use of the death sentence. But the primary theoretical implication concerns repeated finding that states with larger black populations and a history of violent repression directed largely against this racial minority still are likely to use a deadly legal punishment against this racial minority.

\section{WIDER IMPLICATIONS}

Analyses based on aggregate data can detect hidden associations. This study shows that lethal vigilantism in the past and current threats attributable to larger black populations operate in concert to increase death sentences, but an analysis confined to individual offenders could not uncover these relationships. There are other reasons for using a contextual approach.

First, it is unlikely that the court officials or the jurors who decide the death sentence can ignore their social environment. Students of the courts claim that contextual factors in court environments should be given greater attention (Carp and Stidham 1996; Hughes 1995; Jacob 1995). Second, sentencing studies often treat the courts as organizations because external influences on the courts matter. The organizational literature stresses external effects. In contrast to internal factors, environmental accounts have provided far more powerful explanations for organizational behavior. Although most research on criminal sentencing has focused on the race of individual offenders, findings about this controversial issue remain mixed (Chiricos and Crawford 1995; Walker, Spohn, and DeLone 1996; Zatz 1987) and sharply debated, in part because almost all of the many offender level studies analyzing sentencing have assessed this outcome in one or only a few jurisdictions. This study overcomes problems with potentially unrepresentative samples by analyzing the environmental determinants of death sentences over a long period in all state trial courts.

If we compare our results with those from the study investigating the legality of capital punishment (Jacobs and Carmichael 2002), the previous findings show that economic inequality explained whether the death penalty was legal, but that unemployment did not. This pattern is reversed when black death sentences are analyzed. High joblessness rates account for these death sentences, but inequality does not explain either black or all death sentences. Such unemployment results are consistent with a supposition that joblessness leads to mass resentments against underclass capital offenders, but this explanation requires additional support before it can be accepted. The results in this study show that religious fundamentalism leads to increased death sentences, but this factor had no effect on the legality of this punishment in the prior investigation. The political factors that explain the legality of capital punishment also explain the absence of black death sentences in this study. More generally, these findings extend the political perspective on punishment because they show that political factors explain an entirely different set of death penalty outcomes.

This research supports the new political approach in other ways. In theoretical presentations Garland (2001), Savelsberg (1994), and Whitman (2003) provide historical accounts showing how public values shaped criminal punishment. As compared with European societies, political values should have stronger effects on legal sanctions in the United States because of the populistic nature of this most direct of all large democracies. It is not to be expected that mass values will be as influential in Europe, where social policy is decided largely by unelected bureaucrats (Savelsberg 1994; Whitman 2003). These considerations suggest that our findings about political values might not 
hold elsewhere. Results showing that religious and political convictions expressed through acts such as church membership or voting help to explain U.S. death sentences nevertheless enhance the plausibility of a comparative political approach to criminal punishment.

Other cautions are in order. The theoretically interesting findings in this study are suggestive, but they are not definitive. As Tolnay and Beck (1996:238) noted in their careful analysis of the determinants of lynchings, although their (and our) models were specified with the best available theory and research findings considered, model specification in sociology and other nonexperimental disciplines cannot be determined completely by our sometimes less than precise theories. Yet the almost identical results that appeared when we analyzed different samples and dependent variables with different estimation procedures enhance our confidence in the accuracy of these results. We nevertheless hope that this study will encourage additional efforts to detect links between forms of racial repression and the death penalty.

The relationships between prior lynchings and recent death sentences that we have isolated also suggest that vivid historical events continue to influence the current behavior of important social institutions. The finding that acts in the distant past still affect recent legal decisions about who will live and who will die suggests that research that fails to take historical events explicitly into account can produce misleading results. In this instance, results documenting the enduring effects of past racial violence support assertions (Poveda 2000) that the 19th century racial caste system and the violent means used to preserve it help to explain why the United States has adopted such an exceptional stance on the death penalty, as compared with the many equivalent democracies that have so emphatically renounced this punishment. ${ }^{16}$

${ }^{16}$ In contrast to other affluent democracies, only Japan and the United States still use the death penalty. Japan executes fewer than six offenders per year, but U.S. yearly executions have exceeded 21 since 1983. After the 1976 relegalization, mean yearly U.S. executions equaled 28.5 from 1977 to 2000 , and the largest number was 98, in 1999. Claims that the United States is exceptional in its use of this penalty (Poveda 2000; Zimring and Hawkins 1986) there-
The most important implication of these findings concerns racial equity. Repeated results showing that a relationship exists between race and the death penalty are significant because this irreversible sanction should be imposed without racial bias. Yet it is deeply ironic that the only advanced democracy that continues to use the death penalty so often has such an exceptional history of bitter racial conflict (Myrdal 1944). Findings indicating that the past violence used primarily to repress newly freed slaves still contributes to recent death sentences as long as enough African Americans are present do not suggest that the death penalty is currently imposed in a color-blind fashion. If the legal process that produces executions truly were color-blind, this horrific vigilantism should not have such persistent effects. Instead, the historically contingent link that we have detected between recent death sentences and violent repression in the past suggests that both lynchings and current death sentences were and are now partly used for the same repressive ends.

David Jacobs is a Professor of Sociology at Ohio State University. He uses a political economy approach to study the determinants of criminal justice outcomes, economic stratification, and labor relations. Recent publications include cross-national studies of police strength and imprisonment rates, and the factors that explain fluctuations in civil rights protests. Current projects include additional research on capital punishment and other criminal justice outcomes and studies of the political factors that help explain changes in labor management relations.

Jason T. Carmichael is currently a Ph.D. candidate at Ohio State University. He does research on the politics of crime and crime control. He has recently published a study about the factors associated with imprisonment rates across states and another study examining the political explanations for a legal death penalty across the United States. Current projects include a study of states' punitive response toward juvenile offenders and the socioeconomic determinants of police strength.

Stephanie Kent is Assistant Professor of Sociology at the University of Nevada, Las Vegas. Her research interests include the political and social determinants of crime control and outcomes involving the police in U.S. cities. The current work is part of a

fore are difficult to dispute. As Poveda pointed out, U.S. execution frequencies are equivalent to those in authoritarian states such as China or Iran. 
research agenda that includes historical investigation of capital punishment in the United States and crossnational shifts in the legalization of the death penalty.

\section{REFERENCES}

Ayers, Edward L. 1984. Vengeance and Justice: Crime and Punishment in the Nineteenth Century American South. New York: Oxford University Press.

Bailey, William C. and Ruth Peterson. 1999. "Capital Punishment, Homicide, and Deterrence." Pp. 257-77 in Homicide: A Sourcebook, edited by M. Duayne Smith and Margaret A. Zahn. Thousand Oaks, CA: Sage.

Barkan, Steven E. and Steven F. Cohn. 1994. "Racial Prejudice and Support for the Death Penalty." Journal of Research in Crime and Delinquency 31:202-9.

Beckett, Katherine. 1997. Making Crime Pay: Law and Order in Contemporary American Politics. New York: Oxford.

Berry, William D., Evan J. Ringquist, Richard C. Fording, and Russell L. Hanson. 1998. "Measuring Citizen and Government Ideology in the States." American Journal of Political Science 42:327-48.

Black, Donald. 1976. The Behavior of Law. New York: Academic Press.

Blalock, Hubert M. 1967. Towards a Theory of Minority Group Relations. New York: Capricorn Books.

Blume, John and Theodore Eisenberg. 1999. "Judicial Politics, Death Penalty Appeals, and Case Selection: An Empirical Study." Southern California Law Review 72:465-503.

Blume, John, Theodore Eisenberg, and Martin T. Wells. 2004. "Explaining Death Row's Population and Racial Composition." Journal of Empirical Legal Studies 1:165-207.

Blumer, Herbert. 1958. "Race Prejudice as a Sense of Group Position." Pacific Sociological Review $1: 3-7$.

Bobo, Lawrence and Vincent Hutchings. 1996. "Perceptions of Racial Group Competition: Extending Blumer's Theory of Group Position in a Multiracial Social Context." American Sociological Review 61:951-72.

Bowers, William J. 1984. Legal Homicide. Boston, MA: Northeastern University Press.

Brace, P. and M. G. Hall. 1997. "The Interplay of Preferences, Case Facts, Context, and Rules in the Politics of Judicial Choice." Journal of Politics 59:1206-23.

Bright, S. B. and P. J. Keenan. 1995. "Judges and the Politics of Death: Deciding between the Bill of Rights and the Next Election in Capital Cases." Boston University Law Review 75:759-835.

Brillon, Yves. 1988. "Punitiveness, Status, and Ideology in Three Canadian Provinces." Pp.
84-110 in Public Attitudes to Sentencing, edited by Nigel Walker and Mike Hough. London, UK: Grover.

Brown, Richard M. 1969. "The American Vigilante Tradition.” Pp. 121-80 in Violence in America: Historical and Comparative Perspectives, edited by Hugh Davis Graham. Washington, DC: Government Printing Office.

Cameron, A. Colin and Previn K. Trivedi. 1998. Regression Analysis of Count Data. New York: Cambridge.

Camic, Charles. 1986. "The Matter of Habit." American Journal of Sociology 91:1039-87.

Carp, Robert A. and Ronald Stidham. 1996. Judicial Process in America. $3 \mathrm{~d}$ edition. Washington, DC: Congressional Quarterly.

Chambliss, William J. 1964. "A Sociological Analysis of the Law of Vagrancy." Social Problems 12:67-77.

Chiricos, Theodore G. and Charles Crawford. 1995. "Race and Imprisonment: A Contextual Assessment of the Evidence." Pp. 281-309 in Ethnicity, Race, and Crime, edited by Darnell Hawkins. Albany, NY: SUNY Press.

Chiricos, Theodore G. and Miriam Delone. 1992. "Labor Surplus and Punishment: A Review and Assessment of Theory and Evidence." Social Problems 39:421-46.

Cohen, Jacob, Patricia Cohen, Stephen D. West, and Leona S. Aiken. 2003. Applied Multiple Regression/Correlation Analysis for the Behavioral Sciences. 3d edition. Hillsdale, NJ: Lawrence Erlbaum Associates.

Collins, W. H. 1918. The Truth about Lynching and the Negro in the South: In Which the Author Pleads That the South Be Made Safe for the White Race. New York: The Neal Publishing Co.

Corzine, Jay, Lin Corzine, and James Creech. 1988. "The Tennant Labor Market and Lynching in the South: A Test of the Split Labor Market Theory." Sociological Quarterly 58:261-78.

Corzine, Jay, James Creech, and Lin Corzine. 1983. "Black Concentration and Lynchings in the South: Testing Blalock's Power-Threat Hypothesis." Social Forces 61:774-96.

Dodge, Lowell, Laurie E. Eckland, Harriet C. Ganson, Lisa Cassady, James L. Flemming, and Douglas M. Sloan. 1990. "Death Penalty Sentencing." Pp. 268-74 in Death Penalty in America, edited by Hugo A. Bedau. New York: Oxford.

Dollard, John. 1957. Caste and Class in Southern Town. Garden City, NY: Doubleday Anchor Books.

Douglas, Mary. 1966. Purity and Danger: An Analysis of Concepts of Pollution and Taboo. New York: Praeger.

Durkheim, Emile. [1895] 1982. The Rules of the Sociological Method, edited by Steven Lukes. New York: Free Press.

Edsal, Thomas B. and Mary D. Edsal. 1991. Chain 
Reaction: The Impact of Race, Rights, and Taxes on American Politics. New York: W.W. Norton.

Erickson, Kai. 1966. Wayward Puritans. New York: John Wiley.

Garland, David. 1990. Punishment and Modern Society. Chicago, IL: University of Chicago Press.

- 2001. The Culture of Control. Chicago,

IL: University of Chicago Press.

Giles, Michael W. and Melanie A. Buckner. 1993.

"David Duke and Black Threat." Journal of Politics

55:702-13.

Giles, Michael W. and Kaenan Hertz. 1994. "Racial

Threat and Partisan Identification." American

Political Science Review 88:317-26.

Grasmick, Harold G., Elizabeth Davenport, Mitchell

B. Chamlin, and Robert Bursik. 1992. "Protestant

Fundamentalism and the Retributive Doctrine of

Punishment." Criminology 30:21-45.

Grasmick, Harold G. and Ann McGill. 1994.

"Religion, Attribution Style, and Punitiveness toward Juvenile Offenders." Criminology 32:23-46.

Hall, Melinda Glenn. 1992. "Electoral Politics and Strategic Voting in State Supreme Courts." Journal of Politics 54:1117-24.

Hanssen, Andrew F. 2004. "Is There a Politically Optimal Level of Judicial Independence." American Economic Review 94:712-29.

Huber, Gregory A. and Sanford C. Gordon. 2004.

"Accountability and Coercion: Is Justice Blind When It Runs for Office." American Journal of Political Science 48:247-63.

Hughes, John C. 1995. The Federal Courts, Politics, and the Rule of Law. New York: HarperCollins.

Jackson, Pamela I. and Leo G. Carroll. 1981. "Race and the War on Crime: The Sociopolitical Determinants of Municipal Police Expenditures." American Sociological Review 46:290-305.

Jacob, Herbert. 1995. Law and Politics in the United States. 2 d edition. Boston, MA: Little, Brown and Company.

Jacobs, David and Jason T. Carmichael. 2001. "The Politics of Punishment across Time and Space: A Pooled Time-Series Analysis of Imprisonment Rates." Social Forces 80:61-89.

. 2002. "The Political Sociology of the Death Penalty: A Pooled Time-Series Analysis." American Sociological Review 67:109-31.

2004. "Ideology, Social Threat, and Death Sentences: Capital Sentencing across Time and Space." Social Forces 83:249-78.

Johnston, Jack. 1984. Econometric Methods. New York: McGraw-Hill.

Johnston, Jack and John DiNardo. 1997. Econometric Methods. New York: McGraw-Hill.

Lacey, Nicola. 1988. State Punishment: Political Principles and Community Values. London, UK: Routledge.

Langworthy, Robert H. and John T. Whitehead. 1986.
"Liberalism and Fear as Explanations for Punitiveness." Criminology 24:575-91.

Levitt, Steven D. 2002. "Deterrence." Pp. 435-50 in Crime: Public Policies for Crime Control, edited by James Q. Wilson and Joan Petersilia. Oakland, CA: Institute for Contemporary Studies.

Liska, Allen E., J. J. Lawrence, and A. Sanchirico. 1982. "Fear of Crime as a Social Fact." Social Forces 60:760-71.

Long, J. Scott. 1997. Regression Models for Categorical and Limited Dependent Variables. Thousand Oaks, CA: Sage.

Long, J. Scott and Jeremy Freese. 2001. Regression Models for Categorical Dependent Variables Using Stata. College Station, TX: Stata Press.

Marable, Manning. 2000. How Capitalism Underdeveloped BlackAmerica. Cambridge, MA: South End Press.

Morgan, David R. and Shelia S. Watson. 1991. "Political Culture, Political System Characteristics, and Public Policies among the American States." Publius 21:31-48.

Myrdal, Gunnar. 1944. An American Dilemma: The Negro Problem and Modern Democracy. New York: Harper and Brothers.

Newport, Frank. 1979. "The Religious Switcher in the United States." American Sociological Review 44:528-52.

Ogburn, William F. 1937. "The Hypothesis of Cultural Lag." Pp. 719-30 in The Making of Society, edited by V. F. Calverton. New York: The Modern Library.

Olzak, Susan. 1990. "The Political Context of Competition: Lynching and Urban Racial Violence." Social Forces 69:395-421.

Osgood, D. Wayne. 2000. "Poisson-Based Regression Analyses of Aggregate Crime Rates." Journal of Quantitative Criminology 16:21-43.

Paternoster, Raymond. 1991. Capital Punishment in America. New York: Lexington Books.

Phillips, Charles D. 1987. "Exploring Relations among Forms of Social Control: The Lynching and Execution of Blacks in North Carolina." Law and Society Review 21:361-74.

Poveda, Tony G. 2000. "American Exceptionalism and the Death Penalty." Social Justice 27:252-67.

Quillian, Lincoln. 1995. "Prejudice as a Response to Perceived Group Threat: Population Composition and Anti-Immigrant and Racial Prejudice in Europe." American Sociological Review 60:586-611.

-. 1996. "Group Threat and Changes in Regional Change in Attitudes toward AfricanAmericans." American Journal of Sociology 102:816-60.

Quillian, Lincoln and Devah Pager. 2002. "Black Neighbors, Higher Crime? The Role of Racial Stereotypes in Evaluations of Neighborhood 
Crime." American Journal of Sociology 107:717-67.

Rankin, Joseph H. 1979. "Changing Attitudes toward Capital Punishment.” Social Forces 58:94-211.

Reed, John Shelton. 1972. "Percent Black and Lynching: A Test of Blalock's Theory." Social Forces 50:356-60.

Rogers, William H. 1993. "Regression Standard Errors in Clustered Samples." Stata Technical Bulletin 13:1923-28.

Rusche, Georg and Otto Kirchheimer. 1939. Punishment and Social Structure. New York: Russell and Russell.

Savelsberg, Joachim J. 1994. "Knowledge, Domination, and Criminal Punishment." American Journal of Sociology 99:911-43.

—. 2004. "Religion, Historical Contingencies, and Institutional Conditions of Punishment." Law and Social Inquiry 27:373-401.

Soss, Joe, Laura Langbein, and Alan R. Metelko. 2003. "Why Do White Americans Support the Death Penalty?" Journal of Politics 65:397-421.

Soule, Sarah A. 1992. "Populism and Black Lynching in Georgia, 1890-1900." Social Forces 71:431-9.

Stinchcombe, Arthur L. [1968] 1987 Constructing Social Theories. Chicago, IL: University of Chicago Press.

Stone, Lawrence. 1987. The Past and Present Revisited. London, UK: Routledge \& Kegan Paul.

Stucky, Thomas D., Karen Heimer, and Joseph B. Lang. 2005. "Partisan Politics, Electoral Competition, and Imprisonment: An Analysis of States over Time." Criminology 43:211-48.

Sutton, John. 2000. "Imprisonment and Social Classification in Five Common-Law Democracies, 1955-1985." American Journal of Sociology 106:350-86.

Taylor, Marylee C. 1998. "How White Attitudes Vary with the Racial Composition of Local Populations: Numbers Count." American Sociological Review 63:512-35.

Tocqueville, Alexis de. [1835] 1948. Democracy in America, edited by Phillips Bradley. New York: Knopf.

Tolnay, Stewart E. and E. M. Beck. 1996. A Festival of Violence: An Analysis of Southern Lynchings, 1882-1930. Urbana and Chicago, IL: University of Illinois Press.

Turk, Austen. 1982. "Social Control and Social Conflict." Pp. 347-372 in Social Control: Views from the Social Sciences, edited by Jack Gibbs. Beverly Hills, CA: Sage.

Wacquant, Loic. 2000. "The New Particular Institution: On the Prison as Surrogate Ghetto." Theoretical Criminology 4:377-89.

Walker, Samuel, Cassia Spohn, and Miriam DeLone. 1996. The Color of Justice: Race, Ethnicity, and Crime in America. Belmont, CA: Wadsworth.

Whitman, James Q. 2003. Harsh Justice: Criminal Punishment and the Widening Divide between America and Europe. New York, New York: Oxford.

Windlesham, Lord. 1998. Politics, Punishment, and Populism. New York: Oxford.

Woodward, C. Vann. 1966. The Strange Career of Jim Crow. New York: Oxford.

Zatz, Marjorie S. 1987. "The Changing Forms of Racial/Ethnic Biases in Sentencing." Journal of Research in Crime and Delinquency 24:69-92.

Zimring, Franklin E. 2003. The Contradictions of American Capital Punishment. New York: Oxford University Press.

Zimring, Franklin E. and Gordon Hawkins. 1986. Capital Punishment and the American Agenda. New York: Cambridge. 